\title{
Intellectual Capital and Environmental Uncertainty on Firm Performance: The mediating role of the value chain
}

\section{Dini Wahjoe HAPSARI ${ }^{1 *}$, Winwin YADIATI ${ }^{2}$, Harry SUHARMAN ${ }^{3}$, Dini ROSDINI ${ }^{4}$}

${ }^{1}$ Doctoral student, Faculty of Economics and Business, Padjadjaran University and lecturer at Telkom University

2,3,4Faculty of Economics and Business, Padjadjaran University

Email:diniwahjoe@gmail.com¹, winwin.yadiati@unpad.ac.id², harry.suharman@unpad.ac.id², dini.rosdini@unpad.ac.id ${ }^{4}$

* Corresponding Author

\author{
Received: 13.09.2021 Accepted: 04.11.2021 Published: 01.12.2021 DOI: 10.47750/QAS/22.185.23
}

\begin{abstract}
This study aims to analyze the effect of the value chain as a mediating on the relationship between intellectual capital and environmental uncertainty on firm performance. Most studies have not included the mediating effect of the value chain in the relationship between intellectual capital and environmental uncertainty to led firm performance. Data were collected from 207 respondents on non-financial state-owned enterprises in Indonesia, using an online survey. Structural Equation Modeling (SEM) was used for analysis and hypothesis testing.

The results showed a significant and direct relationship between intellectual capital on firm performance and also environmental uncertainty on firm performance. Value Chain mediated the intellectual capital and environmental uncertainty, and therefore, the value chain has a positive effect on firm performance. Furthermore, the result indicates that the value chain mediates the effects of intellectual capital and performance uncertainty on firm performance. The research findings suggest that the value chain can be used and is an essential tool for companies to improve their performance.
\end{abstract}

Keywords: intellectual capital, environmental uncertainty, value chain, firm performance

\section{Introduction}

The competitive advantage of the company is evidence of realizing the company's goals. The main goal is to achieve maximum profit, which means that the company must carry out activities effectively and efficiently. Companies are required to improve their performance by using resources more effectively and efficiently to create value-added and compete in a competitive market. The company must compete to improve its performance and focus on two things, namely financial and nonfinancial. It must work in harmony to achieve comprehensive performance. The balanced scorecard (BSC) is a performance measurement system introduced by (Kaplan \& Norton, 2012). BSC prepares managers to have a quick and comprehensive view to determine the results of business operations. BSC measurement using multidimensional performance consists of financial and non-financial measures that include four perspectives. There are financial perspectives, customer perspectives, internal business process perspectives, and learning and growth perspectives.

Economic developments cause business uncertainty and tight competition between business entities. To win in a dynamic business competition, companies must develop a competitive advantage and implement innovative strategies. Porter (1991) explains that competitive advantage cannot be understood only by looking at a company as a whole. Instead, competitive advantage is formed from the company's activities in designing, producing, marketing, delivering, and providing support services for its products.
Internal factors and external factors can influence firm performance. A study related to resource-based theory by (Barney, 2001) stated that the company's internal resources are important factors for companies to achieve and maintain competitive advantage. These resources consist of physical capital resources, human resources, and organizational resources. One approach used in assessing and measuring knowledge assets is intellectual capital (IC), which has become the focus of attention in various fields, including management, information technology, sociology, and accounting (Petty \& Guthrie, 2000). The elements of intellectual capital and measurement design consist of human capital, structural capital, and relational capital. (Bontis, William Chua Chong, \& Richardson, 2000), (Chen \& Zhu, 2004), (Petty \& Guthrie, 2000)

Several researchers from Indonesia and foreign researchers do this research. Bose \& Thomas (2007) conducted a study on the relationship between intellectual capital and company performance using the balanced scorecard and found that intellectual capital has a positive relationship to company performance. It is in line with research (Mehralian, Nazari, \& Ghasemzadeh, 2018) which shows those intellectual capital models measured using human capital, structural capital, and relational capital can lead to increased financial and non-financial performance. Hariyati, Tjahjadi, \& Soewarno (2019) conducted a study on the relationship between intellectual capital and company performance with the population of all manufacturing companies in Java. Prior studies show that intellectual capital is a crucial factor for increasing firm performance. 
From now on, the company faces many challenges for the environmental changes continuously. Managers must be more professional to maintain and improve firm performance from the influence of external environmental uncertainty. As uncertainty in the external environment increases, makes managers have to adapt quickly. This uncertainty is caused by environmental complexity, likes changing the customer preferences and the challenges from the competitors, which makes the manager more innovative in developing products. The variety of suppliers make managers more selective in choosing. Environmental changes can cause environmental uncertainty like unpredictable economic change, rapid technological change, and government policy. The economic changes make the management should make better decisions.

The rapid expansion of technology and its application into various economic activities has opened new business opportunities. Especially, the introduction of various techniques of devices has increased productivity in the company. On the other hand, the business company depends on policies from the local government that usually change following economic conditions. In an uncertain environment, firms need to act fast and more efficiently from the manager. BSC can use management to measure and increase the firm performance comprehensively.

(Lamboll et al., 2018) suggests that the external environment (customer needs and competitor challenge) will affect the value chain. The result of the (Latan, Jabbour, Jabbour, Wamba, \& Shahbaz, 2018) study found a positive relationship between environmental uncertainty and financial performance.

A state-owned enterprise (SOE) is a business entity that has an essential role in organizing the national economy to realize the community's welfare. In developing countries, the state-owned enterprise sector is an integral part of socioeconomic activity. Most state-owned enterprises were established to fulfill the social objectives of the state rather than to maximize profits. Indonesia state-owned enterprises have made a significant contribution to the Indonesian economy. SOEs in Indonesia is expected to become agents of driving the country's economic development. Since 2019, Indonesia has had 114 SOEs which 16 SOEs listed at Indonesia Stock Exchange, 84 SOEs non-listed, and 14 SOEs with special purpose entities. The ministry of state-owned enterprises divided SOEs into 12 clusters.

This study is intended to examine intellectual capital, environmental uncertainty, and the value chain in Indonesia's SOEs. It is also expected to give the SOE managers to implement the intellectual capital and face environmental uncertainty in their business. The following specific objectives have been set to achieve the primary objective :

1. To examine the effect of intellectual capital and environmental uncertainty on firm performance.

2. To identify the mediating role of the value chain in the relationship between intellectual capital and environmental uncertainty on firm performance.

\section{Literature Review and Hypotheses}

Kaplan \& Norton (2012) conducted a study for performance measurement. The study results show that measurements using a financial perspective alone no longer comprehensively represent the company's financial condition. The balanced scorecard is divided into four different perspectives, formed for short-term and long-term purposes. These perspectives are: (1) financial perspective; (2) customer perspective; (3) internal business processes perspective; (4) learning and growth perspective. Porter (1991) developed a value chain theory to explain in detail the core competencies that can explain cost behavior based on a generic strategy so that companies can use it to identify the relationship between value-creating activities based on the highest value expected consumers. The value chain is used for various purposes, namely to understand the behavior of the costs and the sources of differentiation (Shank and Govindarajan: 1993). Porter (1991) classifies it into two activities, namely primary activities (covering inbound logistics, operations, outbound logistics, sales and marketing, services) and supporting activities (covering procurement, research, and technology, human resources, firm infrastructure)

\subsection{The relationship of intellectual capital and firm performance}

Galbraith first coined intellectual Capital in 1969. Intellectual Capital is another term for intangible assets. Lots the definition of intellectual capital expressed by previous researchers. Stewart (1997), as quoted by Pouraghajan et al. (2013), defines intellectual capital as a "new capital organization that intellectual resources like knowledge, information, and experience are as an instrument for creating the capital." Then, Kamel et al. (2011), as quoted by Pouraghajan et al. (2013), defines intellectual capital as "net value" added to firm assets." Masoulas (1998), as quoted by Yu-Shan Chen (2008), defines intellectual capital as "total stocks of all the intangibles assets, knowledge, and capabilities of a company that could create values of competitive advantages, to achieve its excellent goals." Furthermore, Edvinsson and Malone (1997), as quoted by Kamath (2015), stated Intellectual Capital as "knowledge that can be converted into value." Furthermore, Sveiby (1997) defines Intellectual Capital as "the invisible, intangible part of the balance sheet can be classified as a family of three, individual competence, internal structural, and external structure."

The development of the global economy has made intellectual capital necessary as a company's main asset in its business sustainability (Bontis et al., 2000). The balanced scorecard is a strategic performance measurement framework and methodology that focuses on developing and monitoring strategies through performance measures. Bose \& Thomas (2007); Do Rosário Cabrita \& Bontis (2008) stated that the learning and growth perspective is strongly supported by increasing human resources' competence, which is very much needed. The existence of high knowledge and experience makes a human resource able to work optimally. Liu (2017) states that intellectual capital shows that this intangible resource improves company performance. This study recommends the application of intellectual capital to increase the competitive advantage. Based on the concepts and results of previous research that have been described above, the hypothesis is formulated as:

$\mathrm{H} 1$ : Intellectual capital has a significant effect on firm performance

\subsection{The relationship of environmental uncertainty and firm performance}

According to Milliken (1987), environmental uncertainty is a person's inability to predict something accurately from all social and physical factors that directly influence the behavior decision-making of people in the organization. Variable uncertainty environment is measured using indicators: lack of information, inability to know results, and inability to determine possibility. Environmental uncertainty was identified as an essensial factor because of conditions. It can make planning and control difficult. They are planning to be troubled in 


\section{GENERAL MANAGEMENT}

uncertain operating situations due to the unpredictability of future events. Therefore, managers must predict what will happen in the future that can impact the company, then provide broad-scope information, timeliness, aggregate, and integrated which will be helpful for managers when faced with making decisions that affect several segments company. Which is basically, the decision taken by the manager is based on environmental uncertainty internally and externally. Chenhall and Morris (1986) state that the environmental uncertainty manager faces will affect the characteristics of the information it needs. The control environment is the collective impact of various factors towards creating, enhancing, or reducing policy effectiveness and specific procedures.

Jusoh's (2008) research was conducted on 120 manufacturing companies listed on the Kuala Lumpur Stock Exchange (KLSE). Environmental uncertainty is measured based on the complexity of customers, suppliers, and competitors and environmental changes consisting of government, economic and technological regulations. The study results indicate that environmental uncertainty has a negative effect on company performance as measured by the balanced scorecard. Latan, Jabbour, Jabbour, Wamba, \& Shahbaz (2018) argue with an analysis unit of Indonesian companies, showing a negative relationship between environmental uncertainty and performance measurement. Another researcher (Gosselin, 2011) indicates a significant influence between environmental uncertainty and company performance and suggests that a company manager should be able to make balanced measurements for the financial and nonfinancial sides. Based on the concepts and results of previous research that have been described above, the hypothesis is formulated as:

$\mathrm{H} 2$ : Environmental uncertainty has a significant effect on firm performance

\subsection{The relationship of intellectual capital and value chain}

Porter (1991) developed a value chain theory to explain in detail the core competencies that can explain cost behavior based on a generic strategy so that companies can use it to identify the relationship between value-creating activities based on the highest value expected consumers. The value chain is used for various purposes, namely to understand the behavior of the costs and the sources of differentiation (Shank and Govindarajan,1993). Porter (1991) classifies it into two activities, namely primary activities (covering inbound logistics, operations, outbound logistics, sales and marketing, services) and supporting activities (covering procurement, research, and technology, human resources, firm infrastructure).

Research related to intellectual capital on the value chain was carried out (Bornemann \& Wiedenhofer, 2014); the results of this study stated that the support of intangible resources could be a determining factor in a value chain. In addition, (Carlucci, Marr, \& Schiuma, 2004) stated that intellectual capital is knowledge management that can carry out company business activities that provide added value.

Human resource management in SOE is inseparable from the dimensions of human capital, structural capital, and relational capital. The process of hiring employees with the minimum requirements needed for a job and its level, adequate company infrastructure, and company external relations. The implementation of intellectual capital can support all activities in the company. So, the hypothesis relationship between intellectual capital and value chain on Indonesia SOEs :

$\mathrm{H} 3$ : Intellectual capital has a significant effect on the value chain

\subsection{The relationship of environmental uncertainty and value chain}

Environmental uncertainty is identified as a factor important because such conditions can make planning and control difficult. Planning becomes problematic in uncertain operating situations because of unpredictable future events. Therefore, managers must predict what will happen in the future an impact the company, then provide information that is timeliness, aggregate, and integrated, which will be helpful for managers when faced with making decisions that impact several segments company.

Environmental uncertainty is a factor that can affect the value chain (Sawhney, 2006). In this study, one of the roles of managers in the company is how they can unite all opinions in the face of environmental uncertainty from the entire value chain. Lamboll et al. (2018) state that the success of the value chain is determined by how managers can adapt to environmental changes that have much uncertainty. This environmental uncertainty must be addressed immediately with rapid adaptation by managers. Based on the description above, the hypothesis is proposed as:

H4 : Environmental uncertainty has a significant effect on the value chain

\subsection{The relationship of the value chain and firm performance}

The value chain describes the relationship between all company activities, divided into primary activities and supporting activities. Abdullah, Salman, \& Ahmed (2019); Barton (2017) argue that a value chain is a series of interrelated activity systems that have added value to meet company needs. Using the value chain can improve company performance using a balanced scorecard. The implementation of the value chain is a critical factor in the company's competitive advantage, and all primary activities will increase the company's competitive advantage (Helm \& Jones, 2010). Based on the description above, the hypothesis is proposed as:

H5 : Value chain has a significant effect on firm performance

\subsection{The mediating role of the value chain in the relationship between intellectual capital and firm performance}

Competitive advantage can be achieved supported by the company's value chain; all activities starting from the procurement of raw materials, the production process into finished materials that are ready to be sold is well implemented (Porter, 1991). The implementation of the company's activities is supported by the resources owned by the company measured using intellectual capital. In their research results, (do Rosário Cabrita \& Bontis, 2008) explain that in Malaysia, the application of intellectual capital can affect the performance of companies based on the balanced scorecard? All perspectives in the balanced scorecard can be applied if the activities go according to the company's plan. Intangible assets support the implementation of this value chain, in this case, Human Resources, who have competence in their fields and are supported by their capabilities, and the company's infrastructure is measured using intellectual capital. Thus, it is the hypothesis that :

H6 : Value chain has a mediating role in the relationship between intellectual capital and firm performance 


\section{GENERAL MANAGEMENT}

\subsection{The mediating role of the value chain in the relationship between environmental uncertainty and firm performance}

The empirical studies from (Sawhney, 2006) and (Lamboll et al., 2018) state that the success of the value chain is due to the ability of managers to adapt to environmental changes that occur. The ability of managers to adapt to the complexity of the environment caused by producers, consumers, and competitors and environmental changes (due to changes in technology and policies) can support the smooth running of the company's activities. Latan et al. (2018) researched companies in Indonesia, with research results showing that environmental uncertainty can affect company performance. The higher the level of environmental uncertainty becomes a challenge for managers to adapt. The ability of managers to adapt can affect the four perspectives in the balanced scorecard. Thus, the following hypothesis in the context of the SOES in Indonesia is that :

$\mathrm{H} 7$ : Value chain has a mediating role in the relationship between environmental uncertainty and firm performance

Based on the hypothesis that has been described previously, the theoretical conjecture indicates that the company's performance is influenced by intellectual capital and environmental uncertainty. However, the results of previous studies indicate that a value chain is needed to mediate this relationship. Therefore, it is important to study, because the value chain is the ability of managers to adapt to the complexity of the environment caused by producers, consumers, and competitors, and environmental changes (due to changes in technology and policies) can support the smooth running of the company's activities.

The relationship between variables and structural models was tested, as shown in Figure 1.

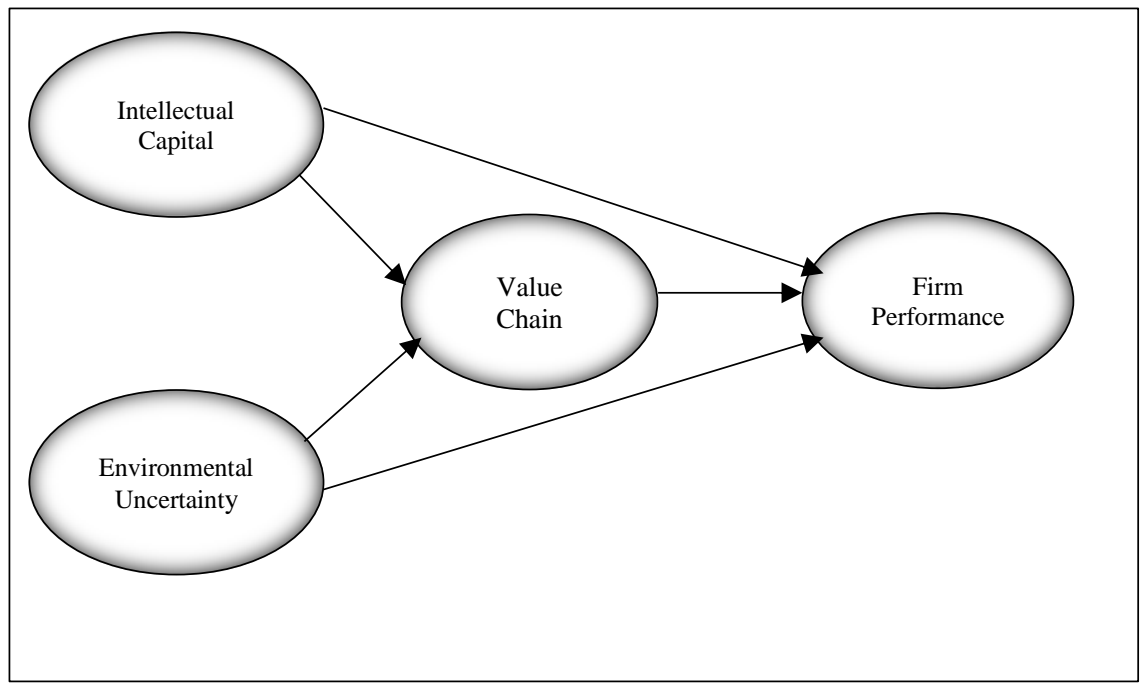

Figure 1: Conceptual model

\section{Research Method}

This study uses a quantitative approach and aims to provide empirical evidence of the influence of intellectual capital and environmental uncertainty on firm performance through the value chain in non-financial state-owned enterprises in Indonesia. This study used a survey method, and data collection was carried out using a questionnaire submitted to respondents via a google form. The population in this study is non-financial state-owned enterprises consisting of 10 clusters and 76 companies. The non-probability sampling technique used is the saturated sample technique. The observation unit consists of the Human Resources Division, the Finance Division, and the Business Development Division, with directors or General Managers as respondents for each division. Human Capital Manager/Director was chosen as the respondent because they are considered to have adequate professional knowledge related to human resource management. Financial managers were selected because they are responsible for the accounting and finance of the company. Business Development managers were chosen because s/he leads and has the authority about innovation strategy. The collected questionnaires were analyzed for completeness and then tabulated. A total of 207 respondents filled out the questionnaire completely.

The operationalization of this research variable is as follows: First, intellectual capital, consisting of 3 dimensions, namely human capital, structural capital, and relational capital using an instrument with a total of 8 statements adopted from (Bontis et al., 2000); (Petty \& Guthrie, 2000); (Chen \& Zhu, 2004). Respondents were asked about intellectual capital related to competency, skills, attitude, infrastructure, and company relationships. Secondly, environmental uncertainty was measured using six questions from (Milliken, 1987), (Daft, 2010); (Wagner III \& Hollenbeck, 2010), (Robbins \& Judge, 2018). Respondents were asked to provide feedback related to environmental complexity and environmental changes facing companies related to market demands, competitors, suppliers, technological developments, and changes in government policies. Thirdly, Value chain variables, measured using nine statements adopted from (Porter, 1991); (Shank \& Ghovindarajan, 1993), (Hoque, 2004). Respondents were asked about the implementation of primary activities and supporting activities. Finally, to measure firm performance variables, using an instrument with a total of 8 statements adopted from (Jusoh, 2008); (Do Rosário Cabrita \& Bontis, 2008), (Bose \& Thomas, 2007). Respondents were asked about their firm performance related to the financial perspective from Return on Assets and Return on Equity (based on KEP100/MBU/2002), customer perspective, internal business processes perspective, learning, and growth perspective. Data analysis using Structural Equation Modeling (SEM) based on variance, with Partial Least Square (PLS) tool. (Hair, 2016) states that PLS uses two measurement stages, namely (1) 


\section{GENERAL MANAGEMENT}

evaluation of measurement model and (2) evaluation of the structural model. Our measurement model measures the level of validity (convergent and discriminant validity) and data reliability. In addition, for demographic data, the descriptive analysis uses partial least square

\section{Results and Discussion/Findings 4.1 Analysis Results}

This study aims to determine the effect of intellectual capital and environmental on firm performance with the meditation role of the value chain. The data were analyzed using structural equation modeling (SEM) with Partial Least Square (PLS) to test the hypothesis.

Before testing the hypothesis, the validity and reliability were tested. Validity test using convergent validity to see the value of loading factor and average variance restricted (AVE), discriminant validity using Fornell-Lacker Criterion. The reliability test saw the value of composite reliability and Conbrach's Alpha. The values of loading factor, average variance extracted (AVE), and reliability are based on model measurements where loading factor $>0.7$; composite reliability $>0.7$, and AVE > 0.50; this provision follows the rule of thumb (Hair, 2016). Table 1 shows all measurement items showing factor loading values above 0.7 and AVE above 0.50, composite reliability values above 0.7 , and Cronbach's Alpha above 0.6. All components are above the recommended values.

\begin{tabular}{|l|l|l|l|l|}
\hline Factors/ltems & $\begin{array}{l}\text { Factor } \\
\text { Loading }\end{array}$ & $\begin{array}{l}\text { Cronbach's } \\
\text { Alpha }\end{array}$ & $\begin{array}{l}\text { Composite } \\
\text { Reliability }\end{array}$ & $\begin{array}{l}\text { Average } \\
\text { Variance } \\
\text { Extracted } \\
\text { (AVE) }\end{array}$ \\
\hline Firm Performance & & $\mathbf{0 . 8 1 2}$ & $\mathbf{0 . 8 6 0}$ & $\mathbf{0 . 5 1 8}$ \\
\hline FP1 & 0.956 & & & \\
\hline FP2 & 0.956 & & & \\
\hline FP3 & 0.864 & & & \\
\hline FP4 & 0.868 & & & \\
\hline FP5 & 0.767 & & & \\
\hline FP6 & 0.831 & & & \\
\hline FP7 & 0.925 & & & \\
\hline FP8 & 0.921 & & & \\
\hline Value Chain & & $\mathbf{0 . 8 4 0}$ & $\mathbf{0 . 8 7 6}$ & $\mathbf{0 . 5 1 7}$ \\
\hline VC1 & 0.750 & & & \\
\hline VC2 & 0.883 & & & \\
\hline VC3 & 0.824 & & & \\
\hline VC4 & 0.752 & & & \\
\hline VC5 & 0.878 & & & \\
\hline VC6 & 0.871 & & & \\
\hline VC7 & 0.823 & & & \\
\hline VC8 & 0.765 & & & \\
\hline VC9 & 0.830 & & & \\
\hline Intellectual Capital & & $\mathbf{0 . 8 9 0}$ & $\mathbf{0 . 9 1 3}$ & \\
\hline IC1 & 0.908 & & & \\
\hline IC2 & 0.733 & & & \\
\hline IC3 & 0.882 & & & \\
\hline IC4 & 0.937 & & & \\
\hline IC5 & 0.902 & & & \\
\hline IC6 & 0.920 & & & \\
\hline IC7 & 0.878 & & & \\
\hline IC8 & 0.902 & & & \\
\hline Environmental Uncertainty & & $\mathbf{0 . 7 7 8}$ & $\mathbf{0 . 8 4 7}$ & \\
\hline EU1 & 0.881 & & & \\
\hline EU2 & 0.751 & & & \\
\hline EU3 & 0.886 & & & \\
\hline EU4 & 0.813 & & & \\
\hline EU5 & 0.840 & & & \\
\hline EU6 & 0.863 & & & \\
\hline & 0.501 & \\
\hline
\end{tabular}

Table 1: Internal Consistency and Convergence Validity Result

After the validity and reliability tests of indicators and variables have been passed, the next step is to assess the results of the evaluation of the structural model and test the hypothesis. First, we do a collinearity test on the structural model using the VIF value. The recommended VIF value is $<5$ for all predictor variables in the model. (Hair, 2016). Table 2 shows the VIF value of all variables below 10, so there is no collinearity in the research model. Next, evaluate the structural model by looking at the coefficient of determination (R2), effect size (f2), and prediction relevance (Q2). R2 describes the variance explained by the endogenous variable construct. Table 2 shows the R2 values of the value chain and firm performance variables are 0.347 and 0.672 . This value indicates a strong relationship between the value chain and firm performance variables. The effect size (f2) value shows the number $0.481 ; 0.061 ; 0.234$ falls into the small and large categories. Finally, Q-square predictive relevance (Q2) measures how well the model's observed values and parameter 


\section{GENERAL MANAGEMENT}

estimates are generated. The value of Q2 (Table 2) shows a value greater than 0.00 , which means the model has predictive relevance.

\begin{tabular}{|l|l|l|l|l|}
\hline Constructs & R2 & f2 & Q2 & VIF \\
\hline Intellectual Capital (IC) & & 0.481 & & 1.192 \\
\hline Environmental Uncertainty (EU) & & 0.061 & & 1.537 \\
\hline Value Chain (VC) & 0.347 & 0.234 & 0.169 & 1.579 \\
\hline Firm Performance (FP) & 0.672 & & 0.305 & \\
\hline
\end{tabular}

Table 2: Structural Model Results

Test the hypothesis using the path coefficient, t-value, and $\mathrm{p}$-value. Hypothesis testing can be seen from the t-statistics and $\mathrm{p}$-value; with the criteria (t-statistics > 1.86) and ( $\mathrm{p}$-value < $0.05)$, the hypothesis is accepted. The path coefficient $(\beta)$ shows the direction of the variable relationship.

Once the measurement model had been ascertained, the next stage was to check the validity of the structural model. To validate the structural model, it was evaluated through essential criteria such as path coefficient $(\beta)$, coefficient of determination for endogenous variables (R2), effect size (f2), prediction relevance (q2) and multicollinearity (inner VIF) (Henseler et al., 2009; Chin 2010; Tenenhaus et al., 2005; Gotz et al., 2010). The threshold value and description for each benchmark are shown in a stepwise test of the structural model below.

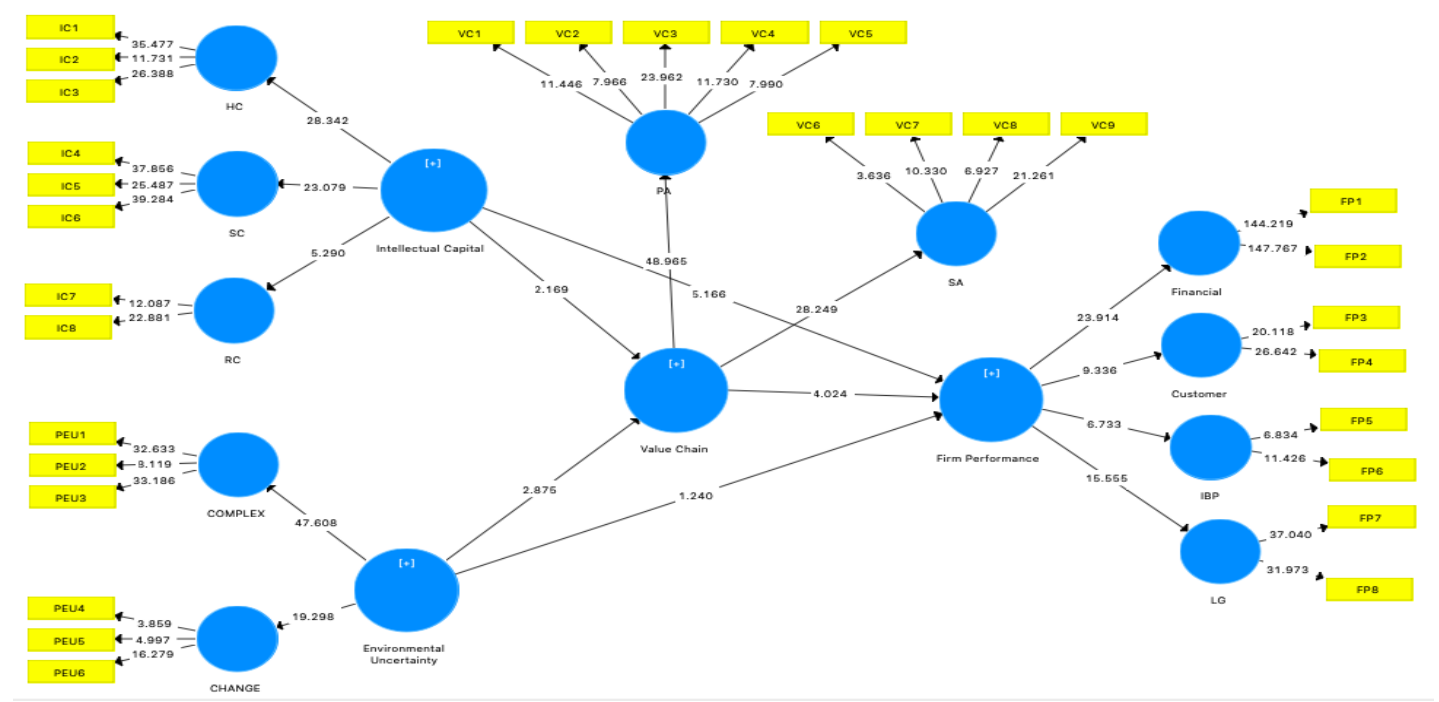

Figure 2: Structural Model (Bootstrapping with inner t-values)

Table 3 shows the direct effect of $\mathrm{H} 1, \mathrm{H} 3, \mathrm{H} 4$, and $\mathrm{H} 5$ accepted. Intellectual capital has a positive effect on financial performance, with path coefficient $(\beta)$ IC $\rightarrow$ FP value of 0.457 and $p$-value $<0.05(\mathrm{H} 1)$. Intellectual capital affects the value chain; this result is indicated by a $p$-value $<0.05$, which means that hypothesis $3(\mathrm{H} 3)$ is accepted. Environmental uncertainty has a positive effect on the value chain, and the path coefficient value indicates this result $(\beta) \mathrm{EU} \rightarrow \mathrm{VC}$ of 0.508 and $\mathrm{p}$-value $<$ $0.05(\mathrm{H} 4)$. The value chain has a positive effect on firm performance, and the path coefficient indicates this result $(\beta)$
VC $\rightarrow$ FP of 0.367 and p-value $<0.05(\mathrm{H} 5)$. While environmental uncertainty does not affect financial performance, this result is indicated by the $p$-value $>0.05$, which means that hypothesis 2 (H2) is rejected.

The indirect effect determines that the value chain mediates the relationship between intellectual capital and firm performance and the relationship between environmental uncertainty and firm performance. The mediation effect was confirmed to be statistically significant, where both the mediating hypothesis was accepted.

\begin{tabular}{|c|c|c|c|c|c|c|}
\hline \multicolumn{2}{|c|}{ Structural Path } & Coeff $(\beta)$ & $\begin{array}{l}\text { Standard Deviation } \\
\text { (STDEV) }\end{array}$ & t-stat & $p$-values & Conclusion \\
\hline \multicolumn{7}{|c|}{ Direct Path } \\
\hline $\mathrm{H} 1$ & $\mathrm{IC} \rightarrow \mathrm{FP}$ & 0.457 & 0.086 & 5.116 & 0.000 & Accepted \\
\hline $\mathrm{H} 2$ & $\mathrm{EU} \rightarrow \mathrm{FP}$ & 0.185 & 0.114 & 1.240 & 0.216 & Rejected \\
\hline $\mathrm{H3}$ & $\mathrm{IC} \rightarrow \mathrm{VC}$ & 0.199 & 0.120 & 2.169 & 0.031 & Accepted \\
\hline $\mathrm{H} 4$ & $\mathrm{EU} \rightarrow \mathrm{VC}$ & 0.508 & 0.132 & 2.875 & 0.003 & Accepted \\
\hline $\mathrm{H} 5$ & $\mathrm{VC} \rightarrow \mathrm{FP}$ & 0.367 & 0.111 & 4.024 & 0.000 & Accepted \\
\hline \multicolumn{7}{|c|}{ Indirect Path } \\
\hline $\mathrm{H} 6$ & $\mathrm{IC} \rightarrow \mathrm{VC} \rightarrow \mathrm{FP}$ & 0.073 & 0.047 & 2.563 & 0.009 & Accepted \\
\hline $\mathrm{H} 7$ & $\mathrm{EU} \rightarrow \mathrm{VC} \rightarrow \mathrm{FP}$ & 0.186 & 0.078 & 2.381 & 0.018 & Accepted \\
\hline
\end{tabular}

Table 3: Relationships between variables 


\subsection{Discussion}

The first hypothesis explains the influence of intellectual capital on firm performance on SOE in Indonesia. The results showed that there was a positive relationship between intellectual capital and firm performance. These results are in line with research (Bose \& Thomas, 2007); (Mehralian et al., 2018); (Hariyati et al., 2019). The results of this study indicate that the role of human capital in terms of knowledge, skills, and attitude, supported by the company's infrastructure and the company's ability to communicate, can improve company performance. The learning and growth perspective is the basis for measuring the company's performance, supported by the appropriate placement of employees, which can improve the internal business processes perspective, supported by ownership of the company's infrastructure. A good business process will produce products following consumer desires to increase consumer loyalty so that the company's income does not decrease.

The second hypothesis shows that environmental uncertainty does not affect firm performance. SOEs are the companies with the highest share ownership owned by the government. For every policy issued by the government, both the central government, the Ministry of SOEs, and other related ministries, management must anticipate and change. SOE is the first company to follow government policy changes, and it should be an example for other private companies. Currently, the development of technology is very fast, so that every company, including SOE, must quickly adapt to be able to compete with competing companies to retain consumers. SOE has a particular policy issued by the Ministry of SOEs to determine suppliers, and each company management complies with the policies issued. Economic changes affect all business activities and apply to all entities, so SOE management must adapt quickly. Therefore, environmental uncertainty is not always able to affect the company's performance.

The third hypothesis explains the influence of intellectual capital on the value chain of SOE in Indonesia. The results showed that there was a positive relationship between intellectual capital and the value chain. These results are in line with research (Bornemann \& Wiedenhofer, 2014). In addition to knowing, employees must have the ability to cooperate in teams (small teams and between divisions and external companies). All actors (in this case, employees) have a role in supporting all activities within the company. In addition, the company provides opportunities to develop employee ideas and innovations to produce better products.

The fourth hypothesis explains the effect of environmental uncertainty on the value chain on SOE in Indonesia. The results showed that there was a positive relationship between intellectual capital and the value chain. These results align with research (Sawhney, 2006) dan (Lamboll et al., 2018), stating that external uncertainty is significant in value chain implementation. Companies are always faced with conditions of uncertainty, both the complexity of consumers and competitors and changes in the economy, government policies, and technological developments. When management can adapt to these changes, it will affect the better business processes measured using the value chain.

The fifth hypothesis explains the effect of the value chain on environmental uncertainty in SOE in Indonesia. The results show that there is a positive relationship between the value chain and firm performance. This result is in line with research (Helm \& Jones, 2010) which states that the integrity of the company's activities will improve firm performance, supported by (Cinquini \& Tenucci, 2010) that the value chain supports the implementation of the company's strategic management. In line with (Abdullah et al., 2019), measuring the value chain using the Porter concept and the study results show that applying all activities in the value chain can produce a good performance. Intellectual capital is a resource owned by the company to improve company performance.

The sixth hypothesis in this study is related to whether intellectual capital affects firm performance through applying the value chain. Based on the statistical analysis results, the value chain positively mediates the relationship between intellectual capital and firm performance. The results of this study are in line with research (Mehralian et al., 2018) which states that one of the factors that can improve company performance is intellectual capital and value chain. Employee management, through intellectual capital, can produce value chain integration (Carlucci et al., 2004). The value chain can use as a tool for companies to improve their performance

The seventh hypothesis in this study is related to whether environmental uncertainty affects firm performance through applying the value chain. The statistical analysis results show that the value chain positively mediates the relationship between environmental and firm performance. These results show the important role of the value chain concerning firm performance. It can be seen from the management's ability to adapt to environmental uncertainty, both the complexity of consumers and competitors as well as economic changes, government policies, and technological developments that keep the company's activities running well (Lamboll et al., 2018) so that the company's performance is always maintained. This argument explains the reasons for the relationship between environmental uncertainty - value chain - firm performance empirically.

\section{Conclusion}

The purpose of this study is to examine the effect of intellectual capital and environmental uncertainty to improve firm performance. This study supports research (Mehralian et al., 2018) dan (van Veen-Dirks \& Lillis, 2018). To expand the test, we include a value chain using the Porter concept. In this paper, we argue that it is necessary to manage resources using intellectual capital and look at environmental uncertainty (external environmental) and value chain implementation to improve company performance. The study results explain that intellectual capital, environmental uncertainty, and value chain can directly improve company performance.

Empirical evidence shows a significant positive effect between intellectual capital and environmental uncertainty on the value chain, and the value chain can improve firm performance. The results of the PLS analysis show that intellectual capital can improve firm performance directly and through the value chain. Meanwhile, environmental uncertainty does not directly affect firm performance, but environmental uncertainty can increase firm performance with the value chain.

Practically, the findings of this study provide an understanding of how state-owned enterprises in Indonesia improve their performance by applying appropriate intellectual capital (starting from the recruitment process to management during work) and the anticipation of managers in facing environmental uncertainty by using value chain mediation. These results can provide a reference to decision-makers within the company to continuously improve performance. Theoretically, the results of this study can enrich findings related to performance in an organization so that it can be used as a reference and tested empirical evidence. The limitation of this research is the relatively small number of samples, only taking non-financial state-owned enterprises. In addition, differences in financial and non-financial companies' business processes cannot be combined for unit analysis. So caution is 


\section{GENERAL MANAGEMENT}

needed in generalizing the results.

\section{References}

[1] Abdullah, H. S., Salman, A. J., \& Ahmed, I. A. (2019). Integrating the value chain and balanced scorecard to evaluate the overall performance of a tourism organization. African Journal of Hospitality, Tourism and Leisure, 8(5), 1-11.

[2] Barney, J. B. (2001). Resource-based theories of competitive advantage: A ten-year retrospective on the resource-based view. Journal of Management, 27(6), 643-650. doi:10.1177/014920630102700602

[3] Barton, D. (2017). Refocusing capitalism on the long term: ownership and trust across the investment value chain. Oxford Review of Economic Policy, 33(2), 188-200. doi:10.1093/oxrep/grx025

[4] Bontis, N., Chua Chong Keow, W., \& Richardson, S. (2000). Intellectual capital and business performance in Malaysian industries. Journal of Intellectual Capital, 1(1), 85-100. doi:10.1108/14691930010324188

[5] Bornemann, M., \& Wiedenhofer, R. (2014). Intellectual capital in education: a value chain perspective. Journal of Intellectual Capital, 15(3), 451-470. doi:10.1108/jic-05-2014-0060

[6] Bose, S., \& Thomas, K. (2007). Applying the balanced scorecard for better performance of intellectual capital. Journal of Intellectual Capital, 8(4), 653-665. doi:10.1108/14691930710830819

[7] Carlucci, D., Marr, B., \& Schiuma, G. (2004). The knowledge value chain: how intellectual capital impacts on business performance. International Journal of Technology Management, 27(6/7), 575. doi:10.1504/ijtm.2004.004903

[8] Chenhall, Robert H., \& Morris, Deigan (1986). The Impact of Structure, Environment, and Interdependence on th Perceived Usefulness of Management Accounting Systems. The Accounting Review, LXI (1), pp. 16-35

[9] Chen, J., Zhu, Z., \& Yuan Xie, H. (2004). Measuring intellectual capital: a new model and empirical study. Journal of Intellectual Capital, 5(1), 195-212. doi:10.1108/14691930410513003

[10] Cinquini, L., \& Tenucci, A. (2010). Strategic management accounting and business strategy: a loose coupling? Journal of Accounting \& Organizational Change, 6(2), 228-259. doi:10.1108/18325911011048772

[11] Daft, R. L. (2010). Organization Theory and Design ' SPfi liriii.

[12] Cabrita, M. D. R., \& Bontis, N. (2008). Intellectual capital and business performance in the Portuguese banking industry. International Journal of Technology Management, 43(1/2/3), 212. doi:10.1504/ijtm.2008.019416

[13] Gosselin, M. (2011). Contextual factors affecting the deployment of innovative performance measurement systems. Journal of Applied Accounting Research, 12(3), 260-277. doi:10.1108/09675421111187692

[14] Hair, J. F. (2016). PLS Hair.pdf.

[15] Hariyati, H., Tjahjadi, B., \& Soewarno, N. (2019). The mediating effect of intellectual capital, management accounting information systems, internal process performance, and customer performance. International Journal of Productivity and Performance Management, 68(7), 1250-1271. doi:10.1108/ijppm-02-2018-0049

[16] Helm, C., \& Jones, R. (2010). Extending the value chain - A conceptual framework for managing the governance of cocreated brand equity. Journal of Brand Management, 17(8), 579589. doi:10.1057/bm.2010.19
[17] Jusoh, R. (2008). Environmental Uncertainty, Performance, and the Mediating Role of Balanced Scorecard Measures Use: Evidence from Malaysia. International Review of Business Research Papers, 4(2), 116-135.

[18] Kamath, G. B. (2015). Impact of Intellectual Capital on Financial Performance and Market Valuation of Firms in India. International Letters of Social and Humanistic Sciences, 48, 107-122. doi:10.18052/www.scipress.com/ilshs.48.107

[19] Lamboll, R., Martin, A., Sanni, L., Adebayo, K., Graffham, A., Kleih, U., ... Westby, A. (2018). Shaping, adapting and reserving the right to play. Journal of Agribusiness in Developing and Emerging Economies, 8(1), 54-76. doi:10.1108/jadee-03-20170036

[20] Latan, H., Jabbour, C. J. C., Jabbour, A. B. de S., Wamba, S. F., \& Shahbaz, M. (2018). Effects of environmental strategy, environmental uncertainty and top management's commitment on corporate environmental performance: The role of environmental management accounting. Journal of Cleaner Production, 180, 297-306. https://doi.org/10.1016/j.jclepro.2018.01.106

[21] Liu, C.-H. (2017). The relationships among intellectual capital, social capital, and performance - The moderating role of business ties and environmental uncertainty. Tourism Management, 61, 553-561. doi:10.1016/j.tourman.2017.03.017

[22] Mehralian, G., Nazari, J. A., \& Ghasemzadeh, P. (2018). The effects of knowledge creation process on organizational performance using the BSC approach: the mediating role of intellectual capital. Journal of Knowledge Management, 22(4), 802-823. doi:10.1108/jkm-10-2016-0457

[23] Milliken, F. J. (1987). Three Types of Perceived Uncertainty About the Environment: State, Effect, and Response Uncertainty. Academy of Management Review, 12(1), 133-143. doi:10.5465/amr.1987.4306502

[24] Petty, R., \& Guthrie, J. (2000). Intellectual capital literature review. Journal of Intellectual Capital, 1(2), 155-176. doi:10.1108/14691930010348731

[25] Pouraghajan, A., Ramezani, A., \& Mohammadzadeh, S. (2013). Impact of Intellectual Capital on Market Value and Firms Financial Performance: Evidence from Tehran Stock Exchange. World of Science Journal , 1 (12), 197-208.

[26] Porter, M. E. (1991). Towards a dynamic theory of strategy. Strategic Management Journal, 12(S2), 95-117. doi:10.1002/smj.4250121008

[27] Robbins, S. P., \& Judge, T. A. (2018). Organizational Behavior.

[28] Sawhney, R. (2005). Interplay between uncertainty and flexibility across the value-chain: Towards a transformation model of manufacturing flexibility. Journal of Operations Management, 24(5), 476-493. doi:10.1016/j.jom.2005.11.008

[29] ERIK SVEIBY, K. (1997). The Intangible Assets Monitor. Journal of Human Resource Costing \& Accounting, 2(1), 73-97. doi:10.1108/eb029036

[30] Van Veen-Dirks, P. M. G., \& Lillis, A. M. (2018). Chapter 2 Do the Motives for Adoption of the Balanced Scorecard Affect its Development and Use? Studies in Managerial and Financial Accounting, 15-37. doi:10.1108/s1479-351220180000033002

[31] Wagner III, J. A., \& Hollenbeck, J. R. (2010). Organizational Behavior, Securing Competitive Advantage.

[32] Chen, Y.-S. (2007). The Positive Effect of Green Intellectual Capital on Competitive Advantages of Firms. Journal of Business Ethics, 77(3), 271-286. doi:10.1007/s10551-006-9349-1 